\title{
Unilateral low-frequency hearing loss after spinal anesthesia: a case report
}

\author{
Spinal anestezi sonrası tek taraflı düşük frekanslı işitme kaybı: olgu sunumu
}

\author{
(DVildan Kölükçü ${ }^{1}$, DMehtap Gürler Balta ${ }^{2}$ \\ ${ }^{1}$ Tokat Zile State Hospital, Anesthesiology and Reanimation Department, Tokat, Turkey \\ ${ }^{2}$ Tokat Gaziosmanpaşa University, Faculty of Medicine, Department of Anesthesiology and Reanimation, Tokat, Turkey
}

Cite this article as/Bu makaleye atıf için: Kölükçü V, Gürler Balta M. Unilateral low-frequency hearing loss after spinal anesthesia: a case report. J Health Sci Med 2020; 3(4): 483-486.

\begin{abstract}
Spinal anesthesia is a frequently used anesthesia technique, which brings an increased risk of associated complications. Hearing loss after spinal anesthesia is rare and usually seen in low-frequency. It can occur uni- or bilaterally and have a permanent or temporary course. This study presents a case who underwent ankle arthroscopy with spinal anesthesia and had a hearing loss at the postoperative 30rd hour and discusses the results in the light of current literature.
\end{abstract}

Keywords: Hearing loss, spinal anesthesia, unilateral

\section{öz}

Günümüzde spinal anestezinin yaygın olarak kullanımı komplikasyonlarındaki artışı da beraberinde getirmektedir. Spinal anestezi sonrası işitme kaybı ile nadir olarak karşılaşılmaktadır. Spinal anestezi sonrası görülen işitme kaybı, genellikle düşük frekanstaki seslerde görülmekte, tek ya da çift tarafı tutabilmekte ve kalıcı ya da geçici seyir gösterebilmektedir. Bu çalışmada ayak bileği artroskopisi nedeniyle spinal anestezi uygulanan ve postoperatif 30. saatte işitmede kaybı görülen olgu sunulmuş ve sonuçlar literatür verileri eşliğinde tartışılmıştır.

Anahtar Kelimeler: İşitme kaybı, spinal anestezi, unilateral

\section{INTRODUCTION}

Spinal anesthesia is widely preferred in infraumblical surgeries for its clinical advantages and ease of application. Hearing loss after spinal anesthesia is one of the rare complications of spinal anesthesia. However, it is now encountered more frequently than in previous years due to the increased frequency of spinal anesthesia (1). Sudden hearing loss is defined as $30 \mathrm{~dB}$ or more sensorineural hearing loss over at least three consequent audiometric frequencies occurring within three days or less (2). Hearing loss after spinal anesthesia is usually diagnosed only by audiological examinations without any clinical findings. However, patients can also present to health centers with the complaint of hearing loss in the postoperative period $(3,4)$. Hearing loss after spinal anesthesia usually occurs in the low-frequency, exhibits a uni- or bilateral involvement and may follow a temporary or permanent course (5). Various studies have reported that it can be seen between the postoperative 24 hours and six days after spinal anesthesia (4). Although different approaches are used in its treatment, cases may also show spontaneous recovery (6).

Our study aimed to present the diagnosis and treatment approaches in a case with unilateral, sudden, and transient hearing loss that developed on the first postoperative day after ankle arthroscopy with spinal anesthesia. 


\section{CASE}

A 43-year-old man of $75 \mathrm{~kg}$, who had no known systemic disease was planned ankle arthroscopy under spinal anesthesia. Physical examination and laboratory tests were evaluated as normal during the preanesthetic consultation. He had no history of a previous operation. $\mathrm{He}$ was classified with American Society of Anesthesiologists physical status I and Modified Mallampati score of II. After the patient who was planned to have spinal anesthesia was informed about the procedure, verbal and written consent was obtained. He did not receive premedication on the day of the operation. The subarachnoid space was reached at once via a midline approach at the L4-5 interspace using a $25 \mathrm{G}$ Quincke spinal needle in the sitting position. After free cerebrospinal fluid (CSF) drainage was obtained, $12.5 \mathrm{mg}(2.5 \mathrm{ml})$ of $0.5 \%$ hyperbaric bupivacaine was administered. The sensory block level was determined by the pinprick test and the operation started when it reached the T8 level. Oxygen was given with $2 \mathrm{~L} / \mathrm{min}$ by nasal cannula during the operation. Hemodynamic parameters remained stable throughout the operation and the operation was completed at the 45th minute without any complications.

The patient was hospitalized for one night after the operation. We observed that spinal anesthesia completely disappeared in the postoperative fourth hour. The patient was consulted to us due to a decrease in hearing in the left ear at the postoperative 30rd hour. He had no complaints accompanying hearing loss such as nausea, dizziness, and headache, and no neurological pathology. His cranial nerve examination findings were normal. We learned that the patient had no hearing or balance problems and had not used autotoxic drugs such as aminoglycoside and diuretics before. The audiological examination revealed a normal hearing in the right ear. However, there was a mild sensorineural hearing loss, a $60 \mathrm{~dB}$ at $125 \mathrm{~Hz}$, a $55 \mathrm{~dB}$ at $250 \mathrm{~Hz}$, a $45 \mathrm{~dB}$ at $500 \mathrm{~Hz}$, and a $40 \mathrm{~dB}$ at $1000 \mathrm{~Hz}$ in the left ear (Figure 1).

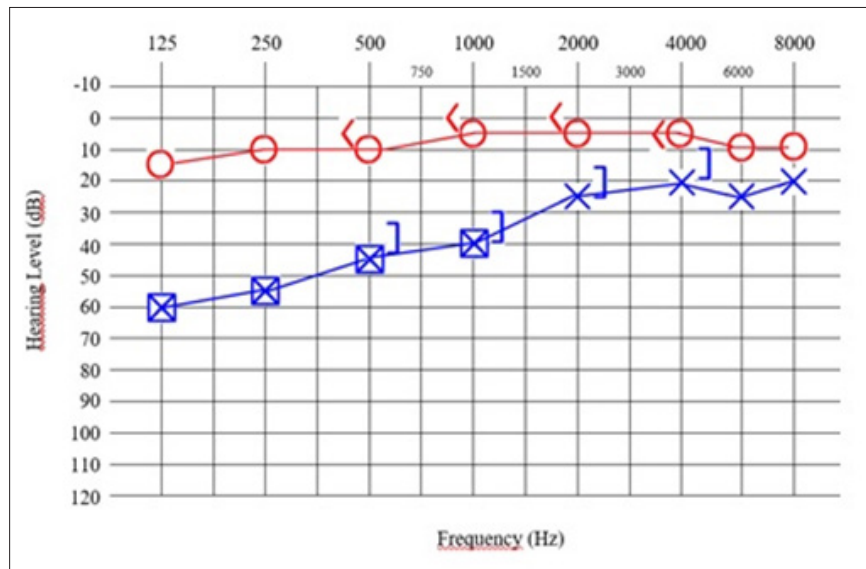

Figure 1. Audiogram on the first postoperative day after spinal anesthesia
Based on the data obtained, the patient was started on medical treatment. He received methylprednisolone $1 \mathrm{mg} / \mathrm{kg}$ intravenously. When he was checked on the fifth day of the treatment, his complaints had completely disappeared and his audiological examination findings were normal (Figure 2). His steroid treatment was reduced and terminated on the 14th day. He had no hearing problems in his follow-up period.

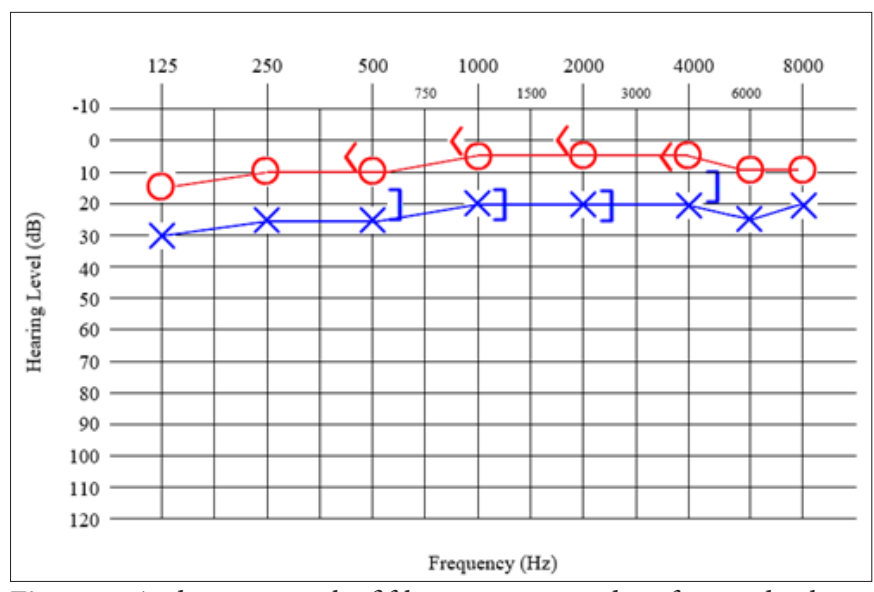

Figure 2. Audiogram on the fifth postoperative day after medical treatment

\section{DISCUSSION}

Hearing loss is one of the rare and late complications of spinal anesthesia. The first case of hearing loss after spinal anesthesia was reported by Terrien et al. (7) in 1914. The cases often have no clinical symptoms and the diagnosis is determined by hearing tests. Therefore, the incidence of hearing loss after spinal anesthesia is observed in a wide range, such as 9-93\% (3). However, the incidence of patients presenting with hearing loss after spinal anesthesia has been reported as $0.2-8 \%$ (4). Although the mechanism of hearing loss due to spinal anesthesia remains uncertain, it is possible to discuss various factors. The side effects of the medications used in anesthesia may be effective in the formation mechanism. It has also been suggested that accompanying ischemic conditions or cerebrospinal fluid leakage due to dural puncture may have a role in hearing loss after spinal anesthesia (8). CSF loss as a result of dural perforation due to lumbar puncture causes a decrease in CSF pressure during spinal anesthesia. In response to CSF loss, perilymphatic fluid passes into the subarachnoid space via the cochlear aqueduct due to the close relationship between middle ear pressure and intracranial pressure, resulting in a decrease in perilymphatic pressure. The relative increase in the endolymphatic pressure observed against the decrease in the perilymphatic pressure causes endolymphatic hydrops. Endolymphatic hydrops leads to displacement in hairy cells in the basilar membrane, resulting in a low-frequency hearing loss $(7,8)$. Hearing loss after spinal anesthesia can be uni- or bilateral and 
may follow a permanent or temporary course. Studies have indicated that hearing loss can be seen between the postoperative 24 hours and six days (4). In our case, the hearing loss occurred on the first postoperative day, and a normal hearing was observed on the fifth day of follow-up and treatment.

The type and diameter of the needles used in spinal anesthesia are also effective factors in the mechanism of hearing loss due to CSF drainage. Several studies have shown that the use of spinal needles of a large diameter, such as $22 \mathrm{G}$, results in a higher incidence of hearing loss than that of spinal needles of a smaller diameter, such as $25 \mathrm{G}$ (3). Erol et al. (9) stated that the incidence of hearing loss was higher after the use of sharp needles than pencil point needles. We encountered a transient low-frequency hearing loss in our case after using a sharp-tip spinal needle of $25 \mathrm{G}$. However, in a study where the spinal needles were of the same diameter and type, the frequency of hearing loss after spinal anesthesia was higher in patients under the age of 30 compared to those over the age of 60 (10). On the other hand Ok et al. (11) stated that patients between 20 to 40 years of age did not have hearing loss after spinal anesthesia.

It is thought that anesthetic agents used also cause hearing loss after spinal anesthesia. A study showed that the use of prilocaine in spinal anesthesia causes hearing loss more frequently than the use of bupivacaine (12). Middle ear pathologies, the use of nonsteroidal anti-inflammatory drugs, diuretics, aminoglycosides, and antineoplastics are also included in the etiology of sudden hearing loss. Hearing loss that develops depending on the duration, dosage and rate of use of these ototoxic drugs often occurs in the high frequencies (4). In our case, hearing loss was observed at low frequencies and there was no known middle ear pathology in the preoperative or ototoxic drug use in the perioperative period.

There is currently no clear consensus algorithm in the treatment of hearing loss after spinal anesthesia. While some clinicians prefer spontaneous recovery without treatment, others emphasize the necessity of treatment (6). There are treatment options such as maintaining the supine position, hydration, intravenous colloid, use of cochlear vasodilator, systemic steroids, or betahistine, hyperbaric oxygen therapy and epidural blood patch $(6,13)$. Although there are different treatment protocols in the literature, the only treatment accepted by everyone is the administration of steroids, which causes a decrease in the endolymphatic pressure and has an anti-inflammatory effect (14). In our study, the patient was diagnosed and started to receive an intravenous steroid treatment on the first postoperative day. When his hearing functions improved on the fifth day of the treatment, his steroid treatment was reduced and terminated, and he was discharged with healing.

\section{CONCLUSION}

Hearing loss after spinal anesthesia is rare; however, as spinal anesthesia becomes more widespread due to its advantages, its complications will increase. It is important to use appropriate equipment, take the necessary precautions and preparations, and inform the surgeon and the patient about possible complications to minimize the complications.

\section{ETHICAL DECLARATIONS}

Referee Evaluation Process: Externally peer-reviewed. Conflict of Interest Statement: The authors have no conflicts of interest to declare.

Financial Disclosure: The authors declared that this study has received no financial support.

Author Contributions: All of the authors declare that they have all participated in the design, execution, and analysis of the paper, and that they have approved the final version.

Informed Consent: Written informed consent was obtained from all participants who participated in this study.

\section{REFERENCES}

1. Cosar A, Yetiser S, Sizlan A, Yanarates O, Yildirim A. Hearing impairment associated with spinal anesthesia. Acta Otolaryngol 2004; 124: 1159-64.

2. Sara SA, Teh BM, Friedland P. Bilateral sudden sensorineural hearing loss: review. J Laryngol Otol 2014; 128: 8-15.

3. Malhotra SK, Joshi M, Grover S. Auditory function following spinal analgesia. Comparison of two spinal needles. Eur J Anesth 2002; 19: 69-72.

4. Sprung J, Bourke DL, Contreras MG, Warner ME, Findlay J. Perioperative hearing impairment. Anesthesiology 2003; 98: 24157.

5. Schaffartzik W, Hirsch J, Frickmann F, Kuhly P, Ernst A. Hearing loss after spinal and general anesthesia: a comparative study. Anesth Analg 2000; 91: 1466-72.

6. Kilickan L, Gürkan Y, Ozkarakas H. Permanent sensorineural hearing loss following spinal anesthesia. Acta Anaesthesiologica Scandinavica 2002; 46: 1155-7.

7. Vilhena D, Pereira L, Duarte D, Oliveira N. Sudden sensorineural hearing loss after orthopedic surgery under combined spinal and epidural anesthesia. Case Rep Otolaryngol 2016; 2016: 4295601.

8. Michel O, Brusis T. Hearing loss as a sequel of lumbar puncture. Ann Otol Rhinol Laryngol 1992; 101: 390-4.

9. Erol A, Topal A, Arbag H, Kilicaslan A, Reisli R, Otelcioglu S. Auditory function after spinal anaesthesia: the effect of differently designed spinal needles. Eur J Anaesthesiol 2009; 26: 416-20.

10. Gültekin S, Ozcan S. Does hearing loss after spinal anesthesia differ between young and elderly patients? Anesth Analg 2002; 94: $1318-20$ 
11.Ok G, Tok D, Erbuyun K, Aslan A, Tekin I. Hearing loss does not occur in young patients undergoing spinal anesthesia. Reg Anesth Pain Med 2004; 29: 430-3.

12. Gültekin S, Yilmaz N, Ceyhan A, Karamustafa I, Kiliç R, Unal N. The effect of different anaesthetic agents in hearing loss following spinal anaesthesia. Eur J Anaesthesiol 1998; 15: 61-3.

13. Yildiz TS, Solak M, Iseri M, Karaca B, Toker K. Hearing loss after spinal anesthesia: the effect of different infusion solutions. Otolaryngology Head and Neck Surgery 2007; 137; 79-82.

14. Tezer MS, Baran Y, Erdur Ö, Ata N, Arslanhan M. Comparison of systemic, intratympanic and combination therapy of the steroids for the treatment of sudden sensorineural hearing loss. Turkiye Klinikleri J Med Sci 2013; 33: 353-9. 